\title{
Penerimaan LGBT oleh Tempat Ibadah
}

\author{
Aureliya Ramadhanti, Suzy S. Azeharie \\ aureliya.915160118@stu.untar.ac.id, suzya@fikom.untar.ac.id \\ Fakultas Ilmu Komunikasi Universitas Tarumanagara
}

\begin{abstract}
LGBT is a sexuality issue that is still being debated in Indonesian society, especially in the religious scope. The church, as a place of worship which is a community with the same belief to worship, has teachings with an interpretation that considers LGBT a sin. Gereja Komunitas Anugerah and the Metropolitan Community Church of Toronto are churches that openly accept $L G B T$ congregations. The two churches are trying to support LGBT congregations by holding activities that discuss the rights of LGBT congregations. This research wants to know how the acceptance of LGBT congregations by churches as a place of worship in Indonesia. Researchers review from the communication side, communication functions and goals. The method used in this research is a phenomenological method with a qualitative descriptive approach. The research data were obtained from in-depth interviews, direct observation, document study and literature study. The conclusion of this research is that the church as a place of worship accepts LGBT because it has a meaning of the holy book verse. Acceptance is carried out by communicating with LGBT people, supporting, instilling religious values, and inviting them to be involved in activities at places of worship.
\end{abstract}

Keywords: LGBT, communication, church

\begin{abstract}
Abstrak
LGBT merupakan isu seksualitas yang masih menjadi perdebatan di masyarakat Indonesia, khususnya pada lingkup keagamaan. Gereja sebagai tempat ibadah yang merupakan suatu komunitas dengan kepercayaan yang sama untuk beribadah pada umumnya memiliki ajaran dengan tafsiran yang menganggap bahwa LGBT merupakan suatu dosa. Gereja Komunitas Anugerah dan Metropolitan Community Church of Toronto adalah gereja yang secara terbuka menerima jemaat LGBT. Kedua gereja tersebut berupaya mendukung jemaat LGBT dengan mengadakan kegiatan yang membahas hak jemaat LGBT. Penelitian ini ingin mengetahui bagaimana penerimaan jemaat LGBT yang dilakukan oleh gereja sebagai tempat ibadah di Indonesia. Peneliti meninjau dari sisi komunikasi, fungsi dan tujuan komunikasi. Metode yang digunakan dalam penelitian ini adalah metode fenomenologi dengan pendekatan deskriptif kualitatif. Data penelitian diperoleh dari wawancara mendalam, pengamatan langsung, studi dokumen dan studi kepustakaan. Kesimpulan penelitian ini adalah gereja sebagai tempat ibadah menerima LGBT karena memiliki pemaknaan terhadap ayat kitab suci. Penerimaan dilakukan dengan berkomunikasi dengan para LGBT, mendukung, menanamkan nilai-nilai agama, dan mengajak ikut terlibat dalam kegiatan di tempat ibadah.
\end{abstract}

Kata Kunci: LGBT, komunikasi, gereja 


\section{Pendahuluan}

Lesbian Gay Biseksual Transgender (LGBT) isu seksualitas yang masih menjadi perdebatan di masyarakat Indonesia. Menurut Rohmawati (2016:310), lesbian adalah perempuan yang tertarik secara personal dengan sesama perempuan. Gay merupakan seorang pria yang memiliki ketertarikan dengan sesama pria. Biseksual adalah seseorang yang memiliki ketertarikan dengan laki-laki dan perempuan secara bersamaan. Transgender merupakan istilah untuk orang yang memiliki cara berperilaku atau penampilan tidak sesuai dengan jenis kelaminnya. LGBT masih menjadi perdebatan di kalangan masyarakat khususnya menuai kontra dalam pandangan agama. Masyarakat Indonesia yang menganut kebudayaan timur masih menganggap bahwa LGBT merupakan orang-orang yang menyimpang dan tidak mentaati ajaran agama yang ada (Ghozali, 2017:31).

Di dalam agama Kristen, ajaran mengenai orientasi seksual memiliki beberapa tafsiran. Meski demikian sebagian besar masyarakat Kristen di Indonesia menolak adanya penyimpangan seksual karena mengacu pada ayat-ayat dalam Kitab Kejadian yang membahas mengenai prokreasi serta ayat-ayat mengenai kaum Sodom dan Gomora yang dikatakan mendapatkan penghukuman oleh Tuhan karena penyimpangan seksual yang dilakukan (Salsabila, 2019:3). Gereja disebut suatu komunitas yang memiliki kepercayaan yang sama atau secara fisik banyak orang yang menyebutkan gereja sebagai sebuah bangunan tempat umat Kristiani berkumpul untuk beribadah (Kusuma, 2009:13).

Gereja Komunitas Anugerah merupakan gereja pertama di Indonesia yang sejak tahun 2015 menyatakan, menerima jemaat LGBT dan menganggap LGBT bukan suatu dosa bagi agama. Sementara di Toronto, terdapat Metropolitan Community Church of Toronto, sebuah gereja yang dibangun oleh seorang homoseksual bernama Robert Wolfe dan sejak tahun 1986 telah aktif memperjuangkan hak kesetaraan LGBT.

Menurut Rogers bersama D Lawrence Kincaid (1981) (dalam Cangara, 2016), komunikasi merupakan suatu proses saat dua orang atau lebih membentuk atau melakukan pertukaran informasi satu sama lainnya, sehingga akan menumbuhkan saling pengertian yang mendalam. Fungsi komunikasi menurut Harold D. Lasswell, merupakan upaya manusia untuk dapat beradaptasi dengan lingkungannya dan upaya untuk pertukaran nilai, perilaku dan peranan (Cangara, 2015:2). Komunikasi menjadi peranan yang penting karena syarat dasar interaksi adalah adanya komunikasi (Sari, Paramita, \& Azeharie, 2019). Menurut Joseph A. DeVito, tujuan komunikasi dibagi menjadi tiga yaitu membentuk seseorang untuk menemukan siapa dirinya, untuk berhubungan dengan orang lain dan meyakinkan pesan yang dikirimkan kepada orang lain supaya orang lain dapat merasa aman (Nurudin, 2016:103).

Dalam isu LGBT yang masih menjadi kontra di lingkup keagamaan penerimaan jemaat LGBT di dalam gereja masih jarang terjadi, khususnya di Indonesia. LGBT dianggap sebagai suatu dosa dan dipaksa untuk kembali menjadi normal. Hal tersebut membuat jemaat LGBT takut untuk jujur mengenai orientasi seksual yang dimilikinya atau bahkan mereka tidak berani ke gereja karena takut dipandang sebelah mata. Namun, Gereja Komunitas Anugerah dan Metropolitan Community Church of Toronto menjadi gereja yang menerima jemaat LGBT secara terbuka dan beranggapan bahwa 
dalam Alkitab tidak disebutkan bahwa LGBT adalah suatu dosa sehingga jemaat LGBT tidak pernah dipaksa untuk kembali menjadi normal.

Berdasarkan judul penelitian di atas, rumusan masalah yang menjadi fokus penelitian ini adalah bagaimana Gereja Komunitas Anugerah dengan Metropolitan Community Church of Toronto dalam menerima jemaat LGBT? apa saja kendala yang terjadi di Gereja Komunitas Anugerah dan Metropolitan Community Church of Toronto dalam penerimaan jemaat LGBT?" Tujuan dari penelitian ini adalah untuk mengetahui cara Gereja Komunitas Anugerah dengan Metropolitan Community Church of Toronto dalam menerima jemaat LGBT dan untuk mengetahui kendala yang terjadi di Gereja Komunitas Anugerah dan Metropolitan Community Church of Toronto dalam melakukan penerimaan jemaat LGBT.

\section{Metode Penelitian}

Penelitian yang dilakukan oleh penulis menggunakan metode penelitian kualitatif. Metode penelitian kualitatif menurut Creswell adalah metode untuk mengeksplorasi dan memahami makna sejumlah individu atau sekelompok orang yang dianggap berasal dari masalah sosial atau kemanusiaan (Creswell, 2010:4).

Dalam penelitian ini, penulis menggunakan pendekatan deskriptif kualitatif dengan metode studi kasus. Dengan pendekatan deskriptif, penulis melakukan pengamatan yang mendalam pada penerimaan jemaat LGBT di Gereja Komunitas Anugerah dan Metropolitan Community Church of Toronto. Kasus adalah fenomena khusus yang hadir dalam suatu konteks yang terbatasi (bounded context), meski batasbatas antara fenomena dan konteks tidak sepenuhnya jelas. Kasus itu dapat berupa individu, peran, kelompok kecil, organisasi, komunitas atau bahkan suatu bangsa (Poerwandari, 2005:108)

Metode pengumpulan data yang penulis lakukan dalam penelitian ini adalah wawancara dengan narasumber, observasi langsung, dokumentasi, studi kepustakaan dan penelusuran data online. Penulis melakukan wawancara dengan tiga narasumber yang dari pihak Gereja Komunitas Anugerah dan Metropolitan Community Church of Toronto. Selanjutnya dari data yang diperoleh saat wawancara dianalisis untuk mengambil kesimpulan penelitian.

Menurut Lexy J. Moleong, keabsahan data adalah setiap keadaan harus mampu mendemonstrasikan nilai yang benar, menyediakan dasar supaya hal tersebut dapat diterapkan dan memperbolehkan keputusan luar yang dapat dibuat tentang konsistensi dari prosedurnya dan kenetralan dari temuan dan keputusan-keputusannya (Moleong, 2011:320). Penelitian ini menggunakan teknik triangulasi yang merupakan teknik pemeriksaan keabsahan data yang memanfaatkan sesuatu yang lain di luar data itu untuk keperluan pengecekan atau sebagai pembanding terhadap data tersebut (Moleong, 2012:330).

\section{Hasil Penemuan dan Diskusi}

1. Gereja Komunitas Anugerah dan Metropolitan Community Church of Toronto 
Gereja Komunitas Anugerah merupakan sebuah lembaga keagamaan yang berdiri sejak tahun 2013. Gereja ini bergerak di bidang humanis sehingga tidak hanya menerima jemaat LGBT namun juga korban penyintas 1965, korban pemutusan kerja sepihak oleh Freeport dan tahanan politik Papua. Jemaat resmi dalam ibadah Minggu berjumlah 48 orang termasuk enam jemaat yang LGBT. Doktrin yang dianut adalah Reformed Baptis yang memiliki tradisi paham kongregasional yaitu jenis pemerintahan gereja yang berpusat pada suatu kongregasi atau jemaat sehingga keputusan yang diambil tidak boleh hanya ditentukan oleh segelintir majelis tetapi harus dikembalikan kepada umat jemaat. Untuk mendukung supaya jemaat dapat bertumbuh secara teologis dan karakter, gereja ini melakukan diskusi setiap hari Selasa, Rabu dan Jumat.

Metropolitan Community Church of Toronto merupakan gereja yang terletak di Toronto Ontario dibangun oleh Robert Wolfe yang merupakan seorang homoseksual dan memiliki pendeta senior bernama Rev. Jeff Rock yang juga merupakan seorang homoseksual. Saat ini ada 200 orang jemaat yang aktif beribadah dengan 150 orang diantaranya adalah LGBT. Gereja berusaha merangkul setiap jemaat melalui grup-grup khusus jemaat agar mereka dapat terhubung satu sama lain. Selain pertemuan ibadah, gejera juga menyelenggarakan workshop, call center dan support group.

2. Penerimaan Jemaat LGBT Oleh Gereja Komunitas Anugerah dan Community Church of Toronto

Pada tahun 2015 Gereja Komunitas Anugerah membuat pernyataan yang dinamakan Sovereignty of Love yang berisi keputusan gereja tersebut yang tegas menerima LGBT dalam pandangan teologis, pandangan psikologis dan pandangan etnis. Gereja tersebut melihat bahwa LGBT bukan merupakan penyimpangan sehingga tidak dapat dianggap sebagai sebuah dosa. Melalui pernyataan tersebut Gereja Kristen Anugerah menjadi gereja pertama di Indonesia yang menerima jemaat LGBT.

Community Church of Toronto merupakan gereja yang sejak awal berdiri tahun 1986 mendukung LGBT karena pendiri gereja tersebut merupakan seorang homoseksual sehingga gereja tersebut memang fokus untuk memperjuangkan hak LGBT. Community Church of Toronto merupakan gereja LGBT pertama di Kanada yang memiliki properti gedung gereja secara pribadi dan sejak awal berdirinya aktif terlibat melakukan kegiatan yang mendukung kesetaraan LGBT.

3. Ajaran Gereja Komunitas Anugerah dan Community Church of Toronto Tentang LGBT

Secara teologi, Gereja Komunitas Anugerah menganggap LGBT bukan merupakan suatu dosa sebab bila membaca kitab Kejadian ketika Allah menciptakan laki-laki dan perempuan maka keduanya diciptakan bukan dari cetakan gambar gender manusia sehingga gender tidak hanya dibagi menjadi lelaki dan perempuan. Gereja tersebut berpendapat ayat yang tertulis di dalam Alkitab tidak dapat dimaknai dengan pemikiran yang kaku. 
Community Church of Toronto melihat misi sosial dan spiritual gereja dengan membela hak-hak minoritas, terutama mereka yang LGBT. Gereja menganggap bahwa LGBT bukan merupakan bentuk dosa karena pada dasarnya segala hal bisa terjadi karena semua manusia ciptaan Tuhan. Oleh karena itu, sejak awal dibangun gereja tersebut secara penuh menyambut jemaat LGBT dan menegaskan bahwa tidak ada yang salah mengenai orientasi seksual seseorang.

4. Dukungan Gereja Komunitas Anugerah dan Community Church of Toronto Terhadap Jemaat LGBT

Gereja Komunitas Anugerah memiliki kegiatan diskusi yang dilakukan setiap hari Jumat membahas tentang LGBT dan kegiatan ini menjadi support group untuk mendukung jemaat LGBT. Secara eksternal gereja tersebut mendukung jemaat LGBT dengan mengikuti konferensi bersama gereja-gereja lain untuk membahas sudut pandang gereja dalam melihat LGBT dan bekerja sama dengan Indonesian Rainbow Christian Fellowship dalam menerbitkan buku terjemahan mengenai homoseksualitas dengan kekristenan.

Community Church of Toronto mendukung berbagai kegiatan untuk jemaat LGBT dengan organisasi yang disebut PFLAG (Parents, Families, and Friends of Lesbians and Gays) yang merupakan organisasi pertama dan terbesar untuk orang-orang LGBT dengan orang tua dan keluarga mereka. Dalam lingkup gereja, gereja tersebut memiliki call center khusus untuk menangani perihal LGBT dan membangun komunitas transeksual yang bernama TREAT (Trans Resource, Education and Advocacy Team). Selain itu sejak tahun 2000 gereja tersebut juga secara aktif melakukan pemberkatan pernikahan sesama jenis.

5. Kendala dalam penerimaan jemaat LGBT di Gereja Komunitas Anugerah dan Metropolitan Community Church Of Toronto

Kendala yang dialami oleh Gereja Komunitas Anugerah adanya protes dari berbagai kalangan masyarakat yang dilontarkan melalui media sosial. Pada tahun 2018, gereja tersebut pernah mendapatkan berita hoax dari satu portal berita Kristen. Gereja Komunitas Anugerah saat ini memilih untuk menghindari setiap kritik yang bersifat provokatif. Jika ada pertanyaan dari orang-orang atau kelompok yang ingin mengetahui alasan keputusan penerimaan jemaat LGBT maka gereja secara terbuka akan menanggapi dan mengajak untuk mengikuti kegiatan gereja.

Sedangkan Metropolitan Community Church of Toronto tidak mendapatkan kesulitan yang berarti pada saat menerima dan melakukan kegiatan-kegiatan mendukung jemaat LGBT karena aturan pemerintah yang sudah memperbolehkan pernikahan sesama jenis.

6. Komunikasi dalam penerimaan jemaat LGBT di Gereja Komunitas Anugerah dan Metropolitan Community Church Of Toronto 
Dalam Gereja Komunitas Anugerah, komunikasi yang terjalin antara jemaat LGBT dengan jemaat yang lainnya berjalan baik. Hal tersebut karena jemaat LGBT tidak terlalu banyak sehingga komunikasi di gereja tersebut dapat berjalan dengan baik. Selain itu pekerja Gereja Komunitas Anugerah juga secara aktif mengajak jemaat LGBT untuk berpendapat.

Sedangkan Metropolitan Community Church of Toronto memiliki jumlah jemaat yang banyak. Walaupun komunikasi yang terjalin berjalan dengan baik namun tidak semua jemaat LGBT dapat berkomunikasi secara akrab antara satu dengan lain. Pekerja gereja tersebut juga terus berusaha supaya dapat berkomunikasi dengan jemaat LGBT baik dengan komunikasi verbal maupun nonverbal.

7. Fungsi komunikasi dalam penerimaan jemaat LGBT di Gereja Komunitas Anugerah dan Metropolitan Community Church of Toronto

Dalam beradaptasi, Gereja Komunitas Anugerah memiliki cara untuk dapat membuat jemaat LGBT beradaptasi dengan baik di gereja dengan membuat kegiatan diskusi di hari Jumat yang memang awalnya merupakan support group atau cell group sehingga pelan-pelan jemaat LGBT dapat beradaptasi dan memiliki rasa menjadi bagian dari komunitas di gereja. Sedangkan jemaat LGBT Metropolitan Community Church of Toronto berjumlah banyak maka membuat jemaat LGBT lebih mudah beradaptasi dengan sesama jemaat lain melalui cell groups yang merupakan upaya gereja untuk membuat jemaat LGBT dapat lebih akrab antara satu dengan lain.

Melalui narasi pada ibadah hari minggu dan kegiatan diskusi di hari Jumat, Gereja Komunitas Anugerah memberikan nilai teologis dan psikologis terhadap jemaat LGBT. Kemudian secara bertahap jemaat LGBT akan diarahkan supaya ikut berperan di dalam lingkungan gereja, dilibatkan dalam kepanitiaan atau menjadi moderator di kegiatan-kegiatan yang dilaksanakan gereja.

Sedangkan di Metropolitan Community Church of Toronto tidak ada grup khusus mengenai pembahasan teologis atau psikologis yang terkait jemaat LGBT karena pada dasarnya mayoritas jemaat LGBT mengaku tidak malu dan tidak ragu untuk mengakui orientasi seksual mereka. Jemaat LGBT berperan aktif khususnya dalam kegiatan-kegiatan sosial untuk memperjuangkan hak kesetaraan LGBT.

8. Tujuan Komunikasi dalam penerimaan jemaat LGBT di Gereja Komunitas Anugerah dan Metropolitan Community Church of Toronto

Pertama, dalam membentuk pribadi jemaat LGBT maka Gereja Komunitas Anugerah dengan terbuka menerima dan mendukung LGBT, juga menggunakan kegiatan diskusi hari Jumat untuk membentuk pribadi jemaat LGBT. Kegiatan pembinaan tersebut membentuk pribadi jemaat LGBT lewat pemikiran yang kritis tentang ajaran yang selama ini dipercaya dan menyambungkan ajaran yang ada dengan teori lain. Sedangkan Metropolitan Community Church of Toronto membentuk jemaat LGBT dengan mengajak 
mereka untuk aktif melakukan kegiatan eksternal guna memperjuangkan keadilan untuk jemaat LGBT. Selain itu jemaat LGBT mengaku bahwa secara tidak langsung mereka mengikuti karakter pendeta gereja yang juga seorang homoseksual.

Kedua, mengenai hubungan, di Gereja Komunitas Anugerah jemaat LGBT dapat berhubungan dengan baik karena memiliki kesempatan untuk mengobrol pasca kegiatan di gereja sehingga terjadi pertukaran informasi dalam menjalin kedekatan dengan kelompok jemaat yang lain. Sedangkan pada Metropolitan Community Church of Toronto, mayoritas jemaat LGBT telah memiliki hubungan yang baik dengan jemaat yang sudah terlebih dahulu beribadah. Setelah kegiatan gereja selesai, jemaat LGBT berupaya untuk berbicara dengan jemaat lainnya tanpa memandang orientasi seksual mereka, selain itu gereja memiliki kegiatan grup jemaat.

Ketiga, dalam hal meyakinkan, Gereja Komunitas Anugerah tidak pernah memaksa jemaat LGBT untuk kembali menjadi normal karena gereja tersebut menganggap bahwa LGBT bukan suatu penyimpangan. Selain itu gereja memberikan kenyamanan karena adanya support group yang menerima orangorang tertindas dan menjadi minoritas. Gereja menjadi komunitas yang tidak hanya sekedar gereja atau teman-teman sekuler. Hal tersebut karena diskusi narasi ibadah, khotbah dan pemahaman mengenai realita. Sedangkan di Metropolitan Community Church of Toronto, gereja merupakan tempat yang ramah bagi semua jemaat LGBT ataupun jemaat heteroseksual. Jemaat LGBT akan diterima sebagaimana diri mereka sendiri secara apa adanya dan tidak akan ada yang diadili dan rasa aman tersebut didukung dengan pernyataan resmi mengenai diakuinya hak pernikahan sesama jenis di Kanada sehingga jemaat LGBT memiliki rasa aman karena keberadaan mereka diakui oleh negara.

\section{Simpulan}

Kesimpulan dari penelitian ini adalah pertama, tempat ibadah umat beragama, dalam hal ini gereja, menerima jemaat LGBT atas pemaknaan terhadap ayat-ayat yang ditulis di dalam kitab suci di mana di dalamnya tidak menyatakan bahwa LGBT merupakan suatu dosa. Oleh karena itu, gereja tidak memaksa jemaat LGBT untuk kembali menjadi normal.

Kedua, gereja memberi dukungan kepada jemaat LGBT dengan berbagai kegiatan baik di dalam maupun di luar gereja. Kegiatan di luar gereja merupakan kegiatan sosial untuk mendukung kesetaraan LGBT dan bekerja sama dengan organisasi lainnya untuk aktif mengikuti kegiatan kampanye LGBT.

Ketiga, walaupun keduanya menerima jemaat LGBT namun terdapat komunikasi yang berbeda dalam hal keeratan hubungan. Hal ini ditentukan oleh jumlah anggota atau jemaat dalam gereja tersebut. Gereja dengan jumlah jemaat lebih sedikit akan memiliki hubungan yang lebih mudah dan erat. Sebaliknya, gereja dengan jumlah jemaat yang lebih besar, cenderung memiliki komunikasi yang berjarak.

Keempat, gereja yang menerima LGBT membentuk support group atau cell group untuk memudahkan jemaat LGBT dalam proses adaptasi di lingkungan gereja. Di 
dalam kelompok tersebut diturunkan nilai teologis dan psikologis. Selain itu, bentuk dukungan terhadap jemaat LGBT juga dilakukan melalui narasi ibadah.

Kelima, gereja menyelenggarakan diskusi sebagai bentuk pembinaan dan meyakinkan jemaat LGBT. Gereja juga mengajak jemaat LGBT untuk memperjuangkan hak kesetaraan LGBT secara eksternal.

Terakhir, gereja yang menerima jemaat LGBT menghadapi tantangan karena harus menghadapi protes masyarakat lewat media sosial. Walau demikian, ada pula yang merasa tidak khawatir karena hukum pernikahan sejenis sudah disahkan di negara di mana gereja tersebut berpusat.

\section{Ucapan Terima Kasih}

Pada kesempatan ini, penulis mengucapkan terima kasih kepada pihak-pihak yang telah banyak membantu dan memberi dukungan selama penelitian ini, yaitu narasumber penulis yang bersedia memberikan data dan mendukung penelitian penulis, keluarga dan teman-teman terdekat penulis yang terus memberikan motivasi dan doa kepada penulis.

\section{Daftar Pustaka}

Cangara, Hafied. (2015). Pengantar Ilmu Komunikasi. Cetakan Kedua. PT. Raja Grafindo Persada. Jakarta.

Cangara, Hafied. (2016). Komunikasi Politik Teori, Konsep dan Strategi, Edisi Revisi. Jakarta: Rajawali Pers.

Creswell, J. W. (2010). Research Design: Pendekatan Kualitatif, Kuantitatif, dan Mixed. Yogyakarta: PT. Pustaka Pelajar.

Ghozali, Malik Abdul. (2017). Fenomena LGBT Dalam Perspektif HAM dan Doktrin

Agama. Jurnal Penelitian Universitas Islam Negeri Syarif Hidayatullah Jakarta Volume 16 Nomor 1.

Kusuma, Adhy Surya. (2009). Gereja Bethany Fresh Anointing di Yogyakarta. Laporan Penelitian Landasan Konseptual Perencanaan dan Perancangan Universitas Atma Jaya Yogyakarta.

Moleong, Lexy J. (2011). Metodologi Penelitian Kualitatif Edisi Revisi. Bandung:PT. Remaja Rosdakarya.

Moleong, Lexy J. (2012). Metodologi Penelitian Kualitatif. Bandung: PT. Remaja Rosdakarya.

Nurudin. (2016). Ilmu Komunikasi: Ilmiah dan Populer. Jakarta: PT. Raja Grafindo Persada

Poerwandari, E. K. (2005). Pendekatan kualitatif untuk penelitian perilaku manusia (edisi ketiga). Depok: LPSP3 Fakultas Psikologi Universitas Indonesia.

Rohmawati. (2016). Perkawinan Lesbian, Gay, Biseksual, dan Transgender atau Transeksual (LGBT) Perspektif Hukum Islam. Ahkam: Jurnal Penelitian Hukum Islam Institut Agama Islam Negeri Tulungagung Volume 4 Nomor 2.

Salsabila, S. A., \& HapsarI, D. (2019). Negosiasi Identitas Homoseksual Dalam Kelompok Keagamaan Kristen. Jurnal Penelitian Universitas Diponegoro. 
Aureliya Ramadhanti, Suzy S. Azeharie: Penerimaan LGBT oleh Tempat Ibadah

Sari, W. P., Paramita, S., \& Azeharie, S. (2019). Kerukunan Dalam Komunikasi Antar Kelompok Agama Islam Dan Hindu Di Lombok. Jurnal Penelitian Komunikasi dan Opini Publik Volume. 23 No 1. 